DOI: $10.15290 /$ bsl.2021.19.12

Creative Commons License: CC BY-SA 4.0

https://creativecommons.org/licenses/by-sa/4.0/deed.en

\author{
Agnieszka Kowalkiewicz-Kulesza \\ Wydział Filologiczny \\ Uniwersytet Łódzki \\ e-mail: agnieszka.kulesza@uni.lodz.pl \\ ORCID: 0000-0002-7979-0441
}

\title{
Przestrzenie tęsknoty w wybranych dramatach Jerzego Szaniawskiego
}

Zagadnienie przestrzeni $\mathrm{w}$ utworach literackich konotuje zjawiska różnorodne i nie zawsze precyzyjnie określone, o czym wspominał już Janusz Sławiński, dokonując uporządkowania perspektyw teoretycznych ${ }^{1}$. Chcąc więc doprecyzować zakres analizy badawczej, muszę zaznaczyć, że mówiąc o przestrzeni w dramatach Jerzego Szaniawskiego, nie będę odnosić się do przestrzeni teatralnej czy scenicznej, ale wyłącznie do przestrzeni tematyzowanej przez bohaterów. Owa przestrzeń jest niezwykle rozbudowana i zróżnicowana, łączy w sobie elementy metaforyczne $\mathrm{z}$ realistycznymi, wpływa na decyzje bohaterów. Świat przedstawiony w większości dramatów Szaniawskiego związany jest z przestrzenią prowincji, którą należy rozumieć jako „kategorię przestrzeni geograficznej, tworzącej opozycję do centrum” ${ }^{2}$. Realistyczna przestrzeń literackich miejsc oddalonych od gwaru wielkiego świata nieustannie będzie kontrastowała z metaforyczną przestrzenią wolności, tęsknoty i marzeń bohaterów. I choć - jak zaznacza Barbara Olech - nie jest łatwo pisać o rozumieniu prowincji przez Szaniawskiego, to prze-

\footnotetext{
1 Por. J. Sławiński, Przestrzeń w literaturze: elementarne rozróżnienia i wstępne oczywistości, w: Przestrzeń i literatura, red. M. Głowiński i A. Okopień-Sławińska, Wrocław-Warszawa-Kraków-Gdańsk 1978, s. 11.

2 E. Kledzik, Prowincja w najnowszej literaturze polskiej i niemieckiej oraz wspótczesnych polonistycznych i germanistycznych badaniach literackich, „Porównania” 2009, nr 6, s. 150.
} 
cież „wyczuwa się, że jest to jedna z tych kategorii, które determinują świat przedstawiony jego dramatów, decydują o oryginalności twórczej"3.

Świat przedstawiony w dramatach Szaniawskiego nie obejmuje zazwyczaj wielkich miast czy dużych zbiorowisk ludzkich. Bohaterowie autora Żeglarza działają raczej na uboczu, w przestrzeni im bliskiej, bezpiecznej, przewidywalnej, np.: dom przy lesie (Dziewczyna z lasu); stara, drewniana kuźnia na tle wiejskiego pejzażu (Kowal, pieniądze i gwiazdy); większe miasto prowincjonalne $^{4} \mathrm{w}$ Chłopcu latajacym; kompleks jezior odseparowanych od świata w jednoaktówce Stużbista; dawna karczma-zajazd mieszcząca się nieopodal rzeki (Most); gospoda Pod Trzema Latarniami (Papierowy kochanek); stary ratusz, w którym można spotkać "typy «jakby z nieprawdziwego zdarzenia»5”, czy sklep zegarmistrza w słuchowisku Zegarek. Wszystkie powyższe miejsca, wpisując się w topos prowincji, uzyskują jednocześnie wymiar uniwersalny, nie znamy ich nazw ani konkretnego umiejscowienia geograficznego - są natomiast nośnikiem ważnej idei, sugerującej, że prowincjonalizm może mieć również charakter metaforyczny i dotyczyć w dużej mierze stanu intelektualnego bohaterów ${ }^{6}$, ponieważ - jak pisał Kazimierz Brakoniecki - prowincja to nie miejsce na mapie, lecz stan umysłu ${ }^{7}$.

Przedmiotem analizy w niniejszym artykule są dwa dramaty: Murzyn. Komedia w trzech aktach z 1917 roku, dramatyczny debiut Szaniawskiego, satyra na obłudę i konwenanse oraz Kowal, pieniądze i gwiazdy. Sztuka w trzech aktach z 1948 roku, powstała już po sukcesie Dwóch teatrów. Oba utwory, mimo że zostały napisane $\mathrm{w}$ odstępie trzydziestu lat, prezentują odmienne światy przedstawione i różnią się kompozycją, przywołują ten sam temat (widocznie bardzo bliski Szaniawskiemu) - potrzebę ucieczki z miejsca, które ogranicza, usypia i blokuje rozwój. Nieakceptowalna przez bohaterów przestrzeń prowincjonalna, w której muszą egzystować, motywuje ich do zmagania się z tą rzeczywistością poprzez przebudowywanie i reorganizację swojej przestrzeni wewnętrznej, duchowej. Jak twierdzi Michał Głowiński,

3 B. Olech, W pogoni za dalą (o dramatach Jerzego Szaniawskiego), w: Doświadczenie prowincji w literaturze polskiej w II poł. XIX i XX wieku, red. E. Paczoska i R. Chodźko, Białystok 1993, s. 52 .

${ }^{4}$ Określenie zawarte w didaskaliach dramatu.

5 Określenie z didaskaliów aktu pierwszego dramatu J. Szaniawskiego Ptak.

6 Zgodnie z przemyśleniami Pascala, który pisał: „Nie w przestrzeni powinienem szukać swej godności, ale w porządku własnej myśli. Nie będę miał więcej posiadając ziemię; przestrzenią wszechświat ogarnia mnie i pochłania jak punkt; myślą ja go ogarniam" [cyt. za: M. Głowiński, Przestrzenne tematy i wariacje, w: Przestrzeń i literatura, s. 79].

7 Por. A. Kowalkiewicz-Kulesza, Wplyw zacisznego Zegrzynka na życie i twórczość Jerzego Szaniawskiego, w: Artysta na prowincji, t. 4, red. J. Jung, B. Małczyński i E. Mika, Ostrava 2019, s. 56-65. 
przestrzeń zwerbalizowana nie jest na ogół przestrzenią bezinteresowną. Mówiąc o niej globalnie, czy też o takim czy innym jej wycinku, zawsze mogę mówić o czymś innym, co należy do świata wyobrażeń moralnych, ideologicznych, religijnych, itp. I tu właśnie ujawnia się wielka rola metaforyki przestrzennej ${ }^{8}$.

I choć nie jest to zjawisko łatwe do uchwycenia i często intuicyjne - jak zauważa dalej badacz - warto przyjrzeć się bohaterom Szaniawskiego i ich „ludzkim przestrzeniom" 9 .

\section{Murzyn. Komedia w trzech aktach (1917)}

Małomiasteczkowość bohaterów tej komedii ujawnia się $\mathrm{w}$ relacjach czarnoskórego, młodego Jima z kobietami z miasteczka. Prostolinijność i bezpośredniość chłopaka kontrastuje z zachowawczym, tradycyjnym życiem innych bohaterów. Wzbudza niepokój i poruszenie wśród nauczycielek, rozbudza namiętność dziewcząt, które są zafascynowane postawą i odmiennością chłopca. Jim w rozmowach z uczennicami ujawnia tęsknotę za życiem pięknym i swobodnym, bo przecież przestrzeń w dramatach bywa opowiadana. Aby ją przywołać - jak konstatuje Anna Krajewska - należy wprowadzić do tekstu dramatycznego elementy narracyjne, dzięki czemu odbiorca wie, że świat i przestrzeń rozciągają się gdzieś poza sceną. Tę przestrzeń czytelnik/widz wypełnia poprzez słowa na zasadzie Ingardenowskich miejsc niedookreślonych, a „przestrzeń powstaje jako odwołanie mimetyczne" ${ }^{10}$. Mentalną przestrzenią Jima stają się nieustanne fantazje o życiu w Afryce, swoją przyszłość wiąże z pragnieniem wyjazdu na czarny ląd, mimo że urodził się $\mathrm{w}$ polskim, prowincjonalnym miasteczku i zdaje sobie sprawę, że nie uda mu się uciec od codziennej, pospolitej egzystencji. Jednak młody chłopak - działając instynktownie i bezceremonialnie - mocno wpływa na wyobraźnię dziewcząt, które dotąd nie miały odwagi marzyć o innym życiu. W niezwykle poetycki i ujmujący sposób Jim opowiada im o swoich onirycznych doznaniach i snuje bajkowe opowieści o życiu w królewskiej rodzinie. Dla Jima nie jest ważne żadne konkretne miejsce na mapie, liczy się jedynie przestrzeń afrykańska, którą traktuje jako element wypełniający pustkę w jego życiu, jakieś „tam”, gdzie widać ,jeszcze więcej kolorów

\footnotetext{
8 M. Głowiński, Przestrzenne tematy i wariacje, w: Przestrzeń i literatura, s. 80.

9 Tamże, s. 81.

10 A. Krajewska, Narracyjne i dramatyczne ujęcia przestrzeni w dramacie XX wieku, w: Przestrzenie we współczesnym dramacie, red. V. Sajkiewicz, E. Wąchocka, Katowice 2009, s. 21.
} 
i wszystko żyje, rusza się, motyle, papugi..."11. Mikołaj Madurowicz, przywołując koncepcję homo localis, zaznaczał, że jej fundamentalnym czynnikiem jest przestrzenność, a człowiek utożsamia się z miejscem oraz utożsamia miejsce jako „własne dopełnienie psychofizyczne i uzupełnienie aksjologiczne"12. Jim w analogiczny sposób traktuje swoje marzenia o Afryce, ta niezbadana przestrzeń stanowi źródło jego aksjologicznego dopełnienia. Leniwy i wiecznie rozmarzony pracownik prowincjonalnego sklepu nie potrafi odnaleźć celu swego życia w miejscu, w którym przebywa - pragnie jedynie odmiennych miejsc. Jim - niczym artysta - staje się $\mathrm{w}$ dramacie kreatorem nierealnych, magicznych przestrzeni, przynoszących mu afektywne ożywienia:

\section{JIM}

No, więc możemy jeść ananasy, strusie jajka upieczone w piasku, pieczeń z młodej żyrafy, dopiero na końcu takie europejskie ciastko z kremem.

[...]

JIM

mówi z wolna, marząc

Tak. - Mój ogród palmowy jest ogromny. [...] W tym ogrodzie [...] są niebieskie jeziora, nad jeziorami latają kolorowe ptaki. Rosną także paprocie - większe niż największy człowiek... Wieczorem wschodzi na niebie księżyc, a w stu moich jeziorach wschodzi sto księżyców. I cały ogród jest pełen jasności. Wszystkie kolory, co zgasły wieczorem, rozżarzają się znowu i znów widać kwiaty, złote pióra ptaków i skrzydła motyle...

milknie - pewien czas cisza

LUSIA

z cicha

Mów jeszcze, Jim...

JIM

milczy - po dość długiej chwili

Czasem zdaje mi się, że ktoś mnie w nocy po cichutku woła: Jim, Jim... wsiądź na okręt, przypłyń do nas, póki jesteś młody... bo potem... Mój ojciec opowiadał, że i jego po nocach wołało, żeby jechał aż za ocean... ale za młodu nie pojechał, więc został tu, przy hotelu... Powiada: „Już przyzwyczaiłem się otwierać gościom drzwi"... Ale ja popłynę, popłynę!

Pauza ${ }^{13}$.

11 J. Szaniawski, Murzyn, w: Dramaty zebrane, t. 1, Kraków 1958, s. 42.

12 M. Madurowicz, Tożsamość homo localis w geografii człowieka, w: Człowiek w badaniach geograficznych, red. W. Maik, K. Rembowska, A. Suliborski, Bydgoszcz 2006, s. 175, cyt. za: E. Rybicka, Geopoetyka. Przestrzeń i miejsce we wspótczesnych teoriach i praktykach literackich, Kraków 2014, s. 246.

13 J. Szaniawski, Murzyn, s. 60. 
Rozbudowany, hiperboliczny opis wyimaginowanej przestrzeni afrykańskiej ma charakter polisensoryczny, łączy w sobie dominujące elementy wizualne $\mathrm{z}$ akustycznymi, a także, biorąc pod uwagę obecność kolorowych kwiatów, również olfaktorycznymi. Warstwa językowo-wizualna staje się zatem medium specyficznej atmosfery afrykańskich przestrzeni. Jednak pomimo piękna prezentowanych fantastycznych wyobrażeń, przebija w słowach Jima świadomość ich nieprawdopodobieństwa. Warto zwrócić uwagę na informacje zawarte $\mathrm{w}$ didaskaliach. $\mathrm{W}$ tym krótkim fragmencie trzykrotnie został zaakcentowany sposób opowiadania Jima, który: najpierw „mówi z wolna, marząc", później milknie, wypowiada się i ponownie milczy. Dołączając do tego dwie pauzy, nie sposób uciec od emocjonalnej interpretacji lirycznej wypowiedzi bohatera, który wyraża w ten sposób swój ukryty smutek i przygnębienie, a nierealistyczna, utopijna przestrzeń Afryki może być rozumiana "jako ekwiwalent stanów uczuciowych" 14 bohatera.

Japoński badacz Yi-Fu Tuan, wyjaśniając różnicę między miejscem a przestrzenią, pisał:

Zamknięta i uczłowieczona przestrzeń staje się miejscem. W porównaniu z przestrzenią, miejsce jest spokojnym centrum ustalonych wartości. Istotom ludzkim potrzebne jest zarówno miejsce, jak i przestrzeń. Życie człowieka jest dialektycznym ruchem między bezpiecznym schronieniem a przygodą, przywiązaniem a wolnością. W otwartej przestrzeni można intensywnie odczuć walory miejsca, a w samotności zacisznego miejsca ogrom rozciągającej się poza nim przestrzeni staje się dojmujący ${ }^{15}$.

A zatem, prowincjonalne miejsce, w którym Jim mieszka i pracuje, czyni jego rzeczywistość realną, niezdobyta przestrzeń natomiast mobilizuje go do refleksji, ale także pobudza tęsknotę, która może zaistnieć w człowieku wtedy, gdy spełniony zostanie „warunek nietożsamości czasowej i przestrzennej" ${ }^{16}$, co potwierdzają słowa wypowiedziane przez Jima: „O Afryko, Afryko! Witaj mi, ziemio, której nie znam, a do której tęskniłem już od wielu lat" 17 .

Afryka - inspirująca dla młodego marzyciela przestrzeń metaforyczna - zniknie niestety wraz ze śmiercią fascynującego marzenia, co spowoduje w zakończeniu dramatu odarcie z wszelkiej nadziei bohatera, który w rozmowie z młodziutką Stasią (traktującą poważnie marzycielską przestrzeń Jima) przyjmie postawę rozczarowanego realisty:

\footnotetext{
14 J. Sławiński, Przestrzeń w literaturze: elementarne rozróżnienia i wstępne oczywistości, s. 21.

15 Yi-Fu Tuan, Przestrzeń i miejsce, przeł. A. Morawińska, Warszawa 1987.

16 W.P. Glinkowski, Transcendencje codzienności. Miejsca. Spotkania. Obsesje, Łódź 2008, s. 71.

17 J. Szaniawski, Murzyn, s. 55.
} 


\section{STASIA}

Jim... dzisiaj widziałam jaskółki, co odlatywały... Tyś mówił, że jaskółka, to taki list. Ja na tym liście napisałam do Afryki, że tam niedługo przyjedziesz - przyjedziesz, póki jesteś młody, bo potem... [...]

JIM

[...] ja już wiem, że taki list, pisany na skrzydłach jaskółczych nie dojdzie... ${ }^{18}$

\section{Kowal, pieniadze i gwiazdy. Sztuka w trzech aktach (1948)}

Pragnienie ucieczki z miejsc bliskich i oswojonych determinuje również bohaterów kolejnego dramatu, którzy podobnie jak Jim, odczuwają głęboką potrzebę zmiany swego życia. Jednak w przeciwieństwie do czarnoskórego chłopca - decydują się na odrzucenie życiowej, bezwartościowej ich zdaniem stagnacji i poddają się dążeniu do nieznanych przestrzeni. Szaniawski tak często w swojej twórczości nazywa tę niezbadaną przestrzeń „dalą", że można uznać ją za słowo-klucz do interpretacji jego dramatów. A zatem, dal to przestrzeń spersonifikowana, kusząca, będąca zaproszeniem do mającego się odbywać ruchu - staje się opozycyjna wobec zaściankowego impasu. Dal jest niesprecyzowanym miejscem przeznaczenia - być może nieistniejącym, ale dla postaci Szaniawskiego nie jest istotne dotarcie do dali i jej zdobycie, lecz nieustanne do niej dążenie, do czegoś nowego, pobudzającego, świeżego, tajemniczego. Dlatego przestrzeń kuszącej dali ewokuje potrzebę włóczęgostwa, której doświadczają bohaterowie dramatu: Jaś, Pani (tancerka) i Zosia. Postaci te spotykają się na kartach dramatu tylko przez chwilę, ale łączy je głębokie zrozumienie własnych potrzeb i oczekiwań, ponadto stają się nośnikami idei dali. Znaczący staje się dialog Pani - doświadczonej tancerki - z Zosią, córką kowala, młodą dziewczyną, która dopiero rozpoczyna dorosłe życie i waha się, czy ulec pragnieniu rozwijania swojego talentu. Kobieta, widząc potencjał muzyczny Zosi, tłumaczy jej, na czym polega artystyczne włóczęgostwo w poszukiwaniu dobrej przestrzeni do samorealizacji:

\section{PANI}

Cóż mam powiedzieć? Należę do rodziny włóczęgów [...]. Do włóczęgów. I to takich prawdziwych - bez żadnej przenośni ... do takich, co muszą, muszą wędrować po świecie. Ktoś z takich, jak ja, powiedział kiedyś: „Nas dal woła" [...]. Takie czy inne wyjaśnienie niedużo mówi tym, co tego w sobie nie

18 Tamże, s. 108. 
mają. Nie rozumieją nas najczęściej policjanci, prokuratorzy, sędziowie, strażnicy graniczni [...]. Czy... rodzice pani zgodzili się od razu i chętnie, żeby pani wstąpiła do konserwatorium?

ZOSIA

Matka nie żyje. [...] A ojciec ... Ojciec zgadza się na wszystko, co zechcę. [...] Czemu pani powiedziała: „My tak wyczuwamy swoich.” Czy ja włóczęga? Ja tak daleko, jak pani, nie jeżdżę. Od naszej kuźni do wielkiego miasta jedzie się tylko osiem godzin.

PANI

tak, osiem godzin to nie jest podróż długa ... ale ... od kowadła do harfy ... tak ... to jednak daleko. [...] spokojna jest pani, cicha, takie ładne, skromne dziewczę, grające przy tym na harfie. Podróże pani od tej kuźni jeszcze nie skończone... gnać coś będzie panią coraz dalej i dalej...19.

Artystyczna dusza Zosi, odziedziczona po biologicznym ojcu, rozwija się $\mathrm{w}$ niej pomimo prowincjonalnego otoczenia i przeświadczenia, że to kowal jest jej prawdziwym tatą. Przestrzeń dziewczęcych marzeń ukazana zostaje poprzez emocjonalny dualizm: $\mathrm{z}$ jednej strony Zosia odczuwa potrzebę wolności i rozwoju, z drugiej - postawa ojca nie pozwala jej uciec od rustykalnej przestrzeni, hamuje jej pomysły i zamiary. Dziewczyna nie potrafi bezceremonialnie odciąć się od wcześniejszego życia, postępować tak radykalnie jak jej biologiczny ojciec Jaś czy córka kupca - jej decyzje uzależnione są od szczerej i prostej miłości kowala. Nie chce ranić uczuć ojca, mówi mu o swoich rozterkach i odczuwaniu nieznanej tęsknoty: „mnie... ciągnie... ciągnie..., żeby iść dalej i dalej w świat... Ale zatrzymywało mnie zawsze na miejscu... zatrzymywał mnie głos $\mathrm{z}$ daleka, co szedł od naszej kuźni... «ty, córko moja». I... zostawałam" ${ }^{20}$. Wyznanie młodej harfistki wprowadza czytelnika $\mathrm{w}$ inny wymiar interpretacji. Jedynie dobroduszna Zosia nie kieruje się w życiu egoizmem, a swoją przestrzeń wolności i tęsknoty łączy z uczuciem miłości do ojca. Dziewczyna nie chce realizować swej twórczej drogi bez akceptacji kochającego kowala. Potrzebuje jego zgody, aby realizować siebie, więc kiedy ją dostaje ze wzruszeniem, ale wewnętrznym spokojem, odjeżdża do miasta, co sugeruje, że wolność i realizacja marzeń w dramacie Szaniawskiego bez dobra i miłości nie ma sensu, wydobywa aksjologiczny wymiar postaci i podkreśla antropocentryczny charakter twórczości Milczka z Zegrzynka ${ }^{21}$.

\footnotetext{
19 J. Szaniawski, Kowal, pieniądze i gwiazdy, w: tegoż, Dramaty zebrane, t. 3, Kraków 1958, s. 173-175 [wyróżnienia - A.K.K.].

20 Tamże, s. 201.

21 Cyt. za: K. Kolińska, Szaniawski. Zawsze tajemniczy, Warszawa 2009.
} 
Dla bohaterów nieokiełznana i niezbadana przestrzeń staje się wyzwaniem i zadaniem. Transcendencja nieznanej dali daje im poczucie wewnętrznej wolności. Przestrzeń wszelkich tęsknot otwiera przed bohaterami to, co do niej przynależy, uświadamia im „ich własną obecność, a także odsłania przed nimi przyszłość, jako rodzaj dalszego czy bardziej odległego «teraz»", bowiem "obecność wyrażana przez przestrzeń nie przemija, lecz - jak powiedziałby Martin Buber - «trwa naprzeciw nas»" 22. W podobnym tonie wypowiada się Witold Glinkowski, konstatując, że:

transcendencja zrywa z wszelką stagnacją. Zachęca do porzucenia tego, co dotychczasowe, co znane i gnuśne, co kapituluje przed rozwojem, przyszłością, zmianą. Transcendencja wzywa do zawieszenia wszelkiego "tu-oto", zanurzonego $\mathrm{w}$ codzienności, wpisanego bez reszty w przedmiotowość, którą zwykliśmy tematyzować, problematyzować, sprowadzać do poziomu powolnego sobie obiektu poznawczej manipulacji ${ }^{23}$.

Słowa te doskonale korespondują z postawą kolejnego bohatera dramatu, Jasia, który tak rozmawia ze swoją kochanką:

\section{JAŚ}

Co bym tu robił? Grywał na weselach? Muszę się jeszcze poduczyć. Wezmę swoje skrzypce i - w świat.

ŻONA

Dlatego, żeby się jeszcze poduczyć?

JAŚ

Dlatego i nie dlatego... Czy ja wiem? Ja tak muszę iść i znowu iść. Ty tego nie zrozumiesz.

ŻONA

Nie rozumiem.

JAŚ

Wy tu wszyscy siedzicie całe lata $\mathrm{w}$ jednym miejscu, $\mathrm{w}$ jednym domu, $\mathrm{w}$ swoim domu... a ja...

ŻONA

Bo nie chcesz mieć swego domu.

JAŚ

Może to i prawda.

22 W.P. Glinkowski, Transcendencje codzienności. Miejsca. Spotkania. Obsesje, s. 63.

23 Tamże, s. 73. 
ŻONA

I co ty tam widzisz $\mathrm{w}$ tym dalekim świecie?

JAS

Nowe miasta, nowe wsie, nowi ludzie.

ŻONA

I kobiety nowe.

JAŚ

Nie. To nie to... (po chwili) Nie; ty tego nie zrozumiesz, ale nie ty jedna ... Coś woła, coś ciągnie, aby dalej. Ktoś taki, jak ja, z takich, jak ja, powiedział: «Nas dal woła».

ŻONA

Dal?

JAŚ

No tak... to miejsce, gdzie niebo styka się z ziemią. Idziemy do tego miejsca, a ono znów daleko od nas... i tak dokoła świata ... (po chwili) Ano ... Zocha... do widzenia ... trzeba iść $[\ldots]^{24}$.

Krótki dialog ukazuje światopoglądowy i intelektualny dysonans między prostoduszną dziewczyną a rozwijającym się (choć nie najmłodszym już ${ }^{25}$ ) skrzypkiem-obieżyświatem. Szaniawski, pielęgnując jakość znaczeń, skupia uwagę czytelnika nie tylko na przekazie werbalnym, ale również na znakach prozodycznych: pauzach, wielokropkach i niedopowiedzeniach, których znajdziemy wiele $\mathrm{w}$ tym krótkim zapisie. Oszczędny dobór słów, a jednocześnie świadomość niewystarczalności ekspresji słownej stają się jak sugeruje Jadwiga Jakubowska ${ }^{26}$ - elementem kompozycyjnym dramatów Szaniawskiego. Niedopowiedzenia Jasia stanowią próbę zdefiniowania jego własnych pragnień. Sam bohater ma kłopot ze sprecyzowaniem odczuć, niedefiniowalne "coś" determinuje jego życie i kieruje uwagę na zdobywanie dali. Jego kochanka, wiejska dziewczyna, nie rozumie emocji Jasia, dziwi się konieczności kształcenia, chęci podróżowania, poszukiwania dróg wolności wewnętrznej. Poetyckie, urywane wypowiedzi Jasia są dla niej egzystencjalną tajemnicą. Uważa, że jego niechęć do stabilizacji wynika z pragnienia romansowania. Jaś natomiast swoją wolność i tęsknotę eksplikuje poprzez odwołanie do przestrzeni. Jego wolność to "dal”, ciągle przesuwająca się li-

\footnotetext{
24 J. Szaniawski, Kowal, pieniądze i gwiazdy, s. 145-147 [wyróżnienie - A.K.K.].

25 Znamienne, że Szaniawski nadaje swojemu trzydziestoletniemu bohaterowi imię Jaś. Zdrobnienie imienia sugeruje, że jest to postać wciąż niedojrzała i poszukująca.

26 J. Jakubowska, Jerzy Szaniawski, Warszawa 1980, s. 7.
} 
nia horyzontu, która - choć nie gwarantuje osiągnięcia celu - jest urzekająca i zniewalająca.

Dal u Szaniawskiego jest więc tajemnicza, nieodgadniona i niemalże mistyczna, a w związku z tym musi wiązać się ze wspomnianym przez Panią „włóczęgostwem”. Janina Abramowska, pisząc o toposie wędrowania, zaznacza:

Wędrowanie (wraz ze swą opozycją - trwaniem w miejscu) należy do najstarszych "dwuplanowych" obrazów poetyckich służących przekazywaniu treści antropologii filozoficznej i etyki. Wydaje się jednak, że także dosłowne, nawet dokumentarne przedstawienia podróży posiadają swoje "sensy głębokie", pozwalają w postaci podróżnika upatrywać ",człowieka w ogóle”, zaś w przestrzennym ukształtowaniu drogi pewien model świata ${ }^{27}$.

Przemierzanie drogi, które staje się symbolem doskonalenia duchowego i jednocześnie sensem egzystencji jest bliskie zarówno Jimowi, jaki i Jasiowi, i Pani. Idąc dalej tropem Abramowskiej, można stwierdzić, że „dom" i „dal” stają się przestrzeniami nacechowanymi zarówno pozytywnie, jak i negatywnie w zależności od osobistych preferencji bohaterów. Dla tancerki czy Jasia sytuacja włóczęgostwa jest wartością samą w sobie, wybór wiecznej tułaczki stanowi istotę życia, a stałe osiedlenie się wyklucza możliwość realizowania własnych aspiracji, ogranicza i unicestwia marzenia. Natomiast dla innych, prowincjonalnych bohaterów dramatów Szaniawskiego "życie cygańskie" jest niezrozumiałe, wręcz kompromitujące - ojciec tancerki, kupiec, kiedy dowiaduje się o życiowym wyborze córki mówi: „Jak się dowiedziałem, powiedziałem: «Nie wpuszczę przez próg!» «Przeklnę». A jestem człowiek twardy. Twardy jestem" 28 .

A zatem przestrzeń tęsknoty i wolności w dramatach Szaniawskiego wyznacza i jednocześnie różnicuje mentalny obszar, w którym funkcjonują bohaterowie utworów. Mówiąc słowami Sławińskiego, staje się „elementem paradygmatycznego porządku świata przedstawionego: współwyznacza matrycę możliwych $\mathrm{w}$ jego ramach opozycji i interakcji" ${ }^{29}$ między postaciami, a nawet - jak obserwujemy to $\mathrm{w}$ dramacie - grupami społecznymi.

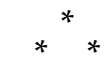

\footnotetext{
27 J. Abramowska, Peregrynacja, w: Przestrzeń i literatura, s. 127.

28 J. Szaniawski, Kowal, pieniądze i gwiazdy, s. 155.

29 J. Sławiński, Przestrzeń w literaturze: elementarne rozróżnienia i wstępne oczywistości, s. 19.
} 
Analiza i interpretacja dramatów autora Dwóch teatrów kieruje uwagę czytelnika ku prowincjonalnym przestrzeniom, w których postaci zmagają się z własną codziennością. Zaakcentowaniu problemu transcendencji i niezgłębionej tęsknoty bohaterów, wyrażanej przestrzeniami metaforycznymi, sprzyja ogólność i niekonkretność określeń stosowanych przez Szaniawskiego. Częsta obecność w dialogach zaimków nieokreślonych tj.: „coś woła", "coś ciągnie", "gnać coś będzie dalej" podkreśla ogromną siłę nie do końca sprecyzowanych pragnień człowieka, a liczne niedopowiedzenia, przemilczenia i pauzy w tekście uwydatniają jego głęboką duchowość i tajemniczość.

Marzenia bohaterów nie uzyskują swej pełnej realizacji, przestrzeń tęsknoty wciąż pozostaje dla nich pociągająca, choć dla Jasia i Pani okazała się w pewien sposób destrukcyjna. Jaś nie zbudował bowiem w życiu żadnego trwałego związku, nie znalazł swojego miejsca w świecie. Kiedy powraca po kilkunastu latach do domu kowala Luśni jest już zmęczonym człowiekiem, ",niemal starym”, ma podczernione włosy, staroświecki żakiet i jasny melonik, jak sugerują didaskalia: „osobliwa elegancja nędzarza” - skrzypce trzyma schowane $\mathrm{w}$ ceratowym woreczku. $\mathrm{Z}$ rozgoryczeniem stwierdza, że nie odnalazł tego, czego szukał, jego pragnienia i tęsknoty nie zrealizowały się; oczekiwana dal nie dała mu szczęścia, nazywa siebie sceptykiem, cynikiem i pesymistą, ma myśli samobójcze. Tancerka natomiast zrealizowała swój cel i osiągnęła sukces, stała się rozrzutna, ale pieniędzy jej nie brakuje, mówi: „Tego i owego w życiu mi często brakowało, ale nie pieniędzy" ${ }^{30}$. Jedyny niedosyt, jaki odczuwa, wynika prawdopodobnie z samotności. Skrzypek i tancerka to postaci najbardziej dojrzałe, choć też najbardziej egoistyczne, doświadczone życiowo, świadome rozczarowań, a tym samym najlepiej radzące sobie z odrzuceniem społecznym i światem realnym.

Jim z kolei, jako młody chłopak, po stracie swego największego marzenia, które kształtowało dotychczas jego codzienność, popada w żałość i cierpi. Tylko wrażliwa i dobroduszna Zosia - jako jedyna z galerii wspomnianych marzycieli - potrafiła pogodzić przestrzeń swej wolności z uczuciem miłości do ojca. Stasia natomiast - ośmioletnia dziewczynka - wciąż wierzy w transcendentne przestrzenie tęsknoty, prawdopodobnie dzięki swej dziecięcej naiwności, którą utracili już pozostali bohaterowie. Tak więc przestrzeń owych transcendentnych tęsknot łączy się nierozerwalnie z przestrzenią świadomości naiwnej ${ }^{31}$, do której Szaniawski również będzie powracał bardzo często

30 J. Szaniawski, Kowal, pieniądze i gwiazdy, s. 185.

31 Zob. R. Sioma, Niewinność i doświadczenie. O komediopisarstwie Jerzego Szaniawskiego, Toruń 2009, s. 101. 
m.in. w dramatach Ptak, Żeglarz czy Papierowy kochanek, uwydatniając tym samym antropologiczny wymiar swoich dzieł, stanowiących doskonałe studium człowieka i jego potrzeb.

\section{Bibliografia}

Abramowska Janina (1978), Peregrynacja, w: Przestrzeń i literatura, red. M. Głowiński, A. Okopień-Sławińska, Wrocław: Zakład Narodowy im. Ossolińskich - Wydawnictwo Polskiej Akademii Nauk, s. 125-158.

Glinkowski Witold (2008), Transcendencje codzienności. Miejsca. Spotkania. Obsesje, Łódź: Biblioteka „Tygla Kultury".

Głowiński Michał (1978), Przestrzenne tematy i wariacje, w: Przestrzeń $i$ literatura, red. M. Głowiński, A. Okopień-Sławińska, Wrocław: Zakład Narodowy im. Ossolińskich - Wydawnictwo Polskiej Akademii Nauk, s. 79-96.

Jakubowska Jadwiga (1980), Jerzy Szaniawski, Warszawa: Wydawnictwa Szkolne i Pedagogiczne.

Kledzik Emilia (2009), Prowincja w najnowszej literaturze polskiej i niemieckiej oraz wspótczesnych polonistycznych i germanistycznych badaniach literackich, "Porównania”, nr 6, s. 150-164.

Kolińska Krystyna (2009), Szaniawski. Zawsze tajemniczy, Warszawa: Państwowy Instytut Wydawniczy.

Kowalkiewicz-Kulesza Agnieszka (2019), Wpływ zacisznego Zegrzynka na życie i twórczość Jerzego Szaniawskiego, w: Artysta na prowincji, t. 4, red. J. Jung, B. Małczyński, E. Mika, Ostrava: Ostravska univerzita we współpracy z Uniwersytetem Humanistyczno-Przyrodniczym im. Jana Długosza w Częstochowie, s. 56-65.

Krajewska Anna (2009), Narracyjne i dramatyczne ujęcia przestrzeni w dramacie XX wieku, w: Przestrzenie we wspótczesnym teatrze i dramacie, red. V. Sajkiewicz, E. Wąchocka, Katowice: Wydawnictwo Uniwersytetu Śląskiego, s. 15-25.

Łotman Jurij (1976), Problem przestrzeni artystycznej, przeł. J. Faryno, „Pamiętnik Literacki", z. 1, s. 213-226.

Łotman Jurij (1975), Zagadnienia przestrzeni artystycznej w prozie Gogola, przeł. J. Faryno, w: Semiotyka kultury, wybór i oprac. E. Janus, M.R. Mayenowa, Warszawa: Państwowy Instytut Wydawniczy, s. 243-295.

Madurowicz Mikołaj (2006), Tożsamość homo localis w geografii człowieka, w: Człowiek w badaniach geograficznych, red. W. Maik, K. Rembowska, A. Suliborski, Bydgoszcz: Wydawnictwo Uczelniane Wyższej Szkoły Gospodarki, s. 169-179.

Olech Barbara (1993), W pogoni za dala (o dramatach Jerzego Szaniawskiego), w: Doświadczenie prowincji w literaturze polskiej w II poł. XIX i XX wieku, red. E. Paczoska, R. Chodźko, Białystok: Filia Uniwersytetu Warszawskiego, s. 52-63.

Rybicka Elżbieta (2014), Geopoetyka. Przestrzeń i miejsce we wspótczesnych teoriach i praktykach literackich, Kraków: Universitas.

Sioma Radosław (2009), Niewinność i doświadczenie. O komediopisarstwie Jerzego Szaniawskiego, Torun: Wydawnictwo Naukowe Uniwersytetu Mikołaja Kopernika. 
Sławiński Janusz (1978), Przestrzeń w literaturze: elementarne rozróżnienia $i$ wstępne oczywistości, w: Przestrzeń i literatura, red. M. Głowiński, A. Okopień-Sławińska, Wrocław: Zakład Narodowy im. Ossolińskich - Wydawnictwo Polskiej Akademii Nauk, s. 9-22.

Szaniawski Jerzy (1958), Dramaty zebrane, t. 1-3, Kraków: Wydawnictwo Literackie.

Tuan Yi-Fu (1987), Przestrzeń i miejsce, przeł. A. Morawińska, Warszawa: Państwowy Instytut Wydawniczy.

\title{
Spaces of Longing in Selected Dramas by Jerzy Szaniawski
}

\begin{abstract}
The aim of this article is to analyse metaphorical spaces in two dramas by Jerzy Szaniawski: Murzyn. Komedia w trzech aktach [A Negro. A comedy in three acts] from 1917 and Kowal, pieniadze i gwiazdy. Sztuka w trzech aktach [A blacksmith, money, and stars. A play in three acts] from 1948. Drawing attention to the fact that the world presented in most of Szaniawski's dramas is connected with the province, the author demonstrates how realistic spaces, far from the tumult of the big world, contrast with the metaphorical spaces of the protagonists' longing, freedom and dreams. These spaces are extremely complex and varied, marking out and at the same time differentiating the mental area in which the protagonists function and influencing their decisions.
\end{abstract}

Keywords: literary space, metaphorical space, drama, Jerzy Szaniawski, province, dream 